\title{
Exploring International Law: Opportunities and Challenges for Political Science Research
}

\author{
A Roundtable
}

\author{
Charlotte Ku, Paul F. Diehl, \\ Beth A. Simmons, Dorinda G. Dallmeyer, \\ and Harold K. Jacobson
}

\section{INTRODUCTION}

\section{Charlotte Ku}

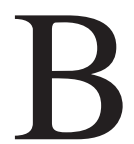

etween 1990 and 1999, only one lead article on international law was published in the American Political Science Review. Moreover, fewer than 10 percent of the articles published in the International Studies Quarterly touched on a subject related to international law. In a decade when questions of restructuring world order dominated, why has international law not figured in the search for answers?

The short essays that follow explain why and, in doing so, they may point the way to opportunities for political science research. The essays grew out of a roundtable organized for the annual meeting of the American Political Science Association in 1999. The roundtable was part of a series that the American Society of International Law organized to address issues arising from teaching or researching international law within the framework of political science and international relations.

Why does work in international relations and political science, which focuses on problems of systemwide change, compliance, and effectiveness of norms and regulations, ignore international law? The question seems simple for an international lawyer because these issues are at the heart of scholarship in international law. The question recently has become more compelling as those with 
principal training in law discover the value of the method and broad framework of political science.

Yet political science seems slow to respond to the enthusiasms of lawyers, and law has been slow to embrace the methods and techniques of political science. Why? The essays prepared here by three prominent political scientists and a distinguished legal research scholar try to answer this question. In doing so, they touch on issues of mentoring, professional reward and recognition, intellectual tradition, and the availability of data from which to conduct meaningful social scientific inquiry.

Do their reflections represent a shift in the present research environment or a continuation of the gap that exists between those who focus on international law and those who focus on international relations? Does a gap present a barrier to research? Do opportunities exist to overcome the gap, or will crossdisciplinary work remain serendipitous? How can individuals interested in overcoming these barriers do so? We hope that by understanding our differences, individuals working in the fields of international law, international relations, and political science will more ably learn and borrow from each other.

The concerns listed above paint a picture of a random crossover principally to enhance an individual research project. This may be the case for the present and so will not immediately solve the warm bodies and pipeline problem Paul Diehl describes. Yet, as opportunities grow for global governance studies to understand changes in norms versus power, perhaps both international lawyers and social scientists will move just far enough away from their intellectual traditions to join in creating new approaches to address new issues, problems, and progress of international relations. These new endeavors may then create the pipeline needed to provide opportunities for graduate work and research. We hope that by understanding some of the challenges, those specializing in international relations, political science, and international law will be able to take advantage of the opportunities provided by our changing world. In so doing, these specialists may break new ground in research through the informed use of perspectives generated by multidisciplinary work as they explore the same problems.

\section{INTERNATIONAL LAW: STEPCHILD \\ in Social ScIEnce Research}

\section{Paul F. Diehl}

Although international law has long been considered one of the distinct subfields of international relations, there is precious little current research on the subject within the social sciences. This has not escaped the attention of scholars. There have been repeated calls from political scientists and international 
lawyers on the need for dialogue and research that reaches across the two disciplines. ${ }^{1}$ Yet there has been more smoke than fire-and more calls for research than actual research that responds to such pleas, even when promising lines of inquiry are identified. ${ }^{2}$ Why are such good intentions not translated into empirical research? I will outline three major problems that constitute barriers to international legal research in political science. ${ }^{3}$ These concerns must be addressed before any of the good ideas offered in this forum can become research realities, lest they join earlier efforts in the orphanage of interesting but largely ignored theoretical questions and puzzles.

\section{BARRIERS TO INTERNATIONAL LAW RESEARCH: The Warm Bodies Problem}

The most fundamental prerequisite for international legal research by social scientists is the availability of trained scholars to do the work. Undergraduate student demand for international law courses is high, but there are relatively few social science faculty specializing in the subject. For example, the typical political science department does not have a specialist in international law, even at major research universities. Although having a specialist in international security or international political economy is considered fundamental for larger political science departments, the presence of an international law specialist is not given the same priority. As is the case with most of international relations, the long-standing dominance of the realist approach was a significant factor in this. The triumph of realism over idealism in the 1950s (and probably before) meant that international law was deemed unimportant and therefore not worthy of theoretical study.

Today, realism no longer holds a hammerlock on the study of international relations. Other approaches (e.g., neoliberalism and constructivism) are perhaps more conducive to the incorporation of international law. Yet many new theoretical approaches are less state-centric (e.g., globalization studies, like

\footnotetext{
${ }^{1}$ Robert Beck, "International Law and International Relations: The Prospects for Interdisciplinary Collaboration," in Robert J. Beck, Anthony Clark Arend, and Robert Vander Lugt, eds., International Rules: Approaches from International Law and International Relations (Oxford, U.K.: Oxford University Press, 1996), pp. 3-33; AnneMarie Slaughter, Andrew S. Tulumello, and Stepan Wood, "International Law and International Relations Theory: A New Generation of Interdisciplinary Scholarship," American Journal of International Law 92, No. 3 (1998), pp. 367-397.

${ }^{2}$ For a contrasting view, see Beck et al., eds. International Rules.

${ }^{3}$ Given the focus of the forum, I do not address the reverse problem-i.e., research by international lawyers that is informed by political science theory and methodology. Nevertheless, this should not imply that such concerns are not important nor that the barriers are any less daunting.
} 
those by James Rosenau, and studies of nongovernmental organizations (NGOs) and transnational networks, like those by Margaret Keck and Katherine Sikkink), which may limit their extension to international legal decisionmaking, still largely a state-driven process. ${ }^{4}$

Exacerbating the limited number of international legal specialists are two characteristics of those who do exist. First, many political scientists teaching international law in the United States and Canada regard international law as a secondary or "teaching" expertise, and not necessarily one in which they conduct primary research. While this addresses curricular gaps for international law, it does nothing to fill the research void. Second, the secular trend until the early 1990s was that the largest cohort of international law specialists was growing increasingly older and nearing retirement; whether this pattern has been reversed in the last decade is uncertain. ${ }^{5}$ To some extent, the small pool of international law specialists has been shrinking over time.

The most direct solution to the warm bodies problem is to train more specialists in international law. Yet this is something of a chicken and egg problem. Most graduate programs (with some notable exceptions such as Georgetown) do not offer courses or field concentrations in international law; this is largely because they lack faculty specialists in that area. Thus graduate students who might have an initial interest in international law do not have active mentors with whom they might work. More important, there is little opportunity for proselytizing, as graduate student interests often evolve according to the courses they take and the interests of the faculty they encounter. Sending such students to take courses in law schools addresses the issue of substantive grounding in the subject matter. Nevertheless, law schools emphasize largely descriptive analyses to assess the status of legal norms. Training in law schools is designed to instill and hone legal reasoning skills, such that key principles of law can be distilled from individual cases. Accordingly, there is often little or no concern for the behavior of states or broad theoretical generalizations, which are the staple of the social sciences.

Pathbreaking work by individuals can transform the study of international relations (note the impact of Hans Morgenthau and Kenneth Waltz). More common, research subjects and approaches gain prominence in the field by having a critical mass of scholars working on key problems. The study of international law from a social science perspective lacks such a critical mass. Perhaps the best hope for achieving this is to stimulate scholars with related interests (e.g.,

\footnotetext{
${ }^{4}$ James Rosenau, Turbulence in World Politics (Princeton, N.J.: Princeton University Press, 1990); Margaret Keck and Katherine Sikkink, Activists beyond Borders: Advocacy Networks in International Politics (Ithaca, N.Y.: Cornell University Press, 1998).

${ }^{5}$ John King Gamble, "Teaching International Law in the 1990s," Studies in Transnational Legal Policy, No. 24 (1993).
} 
those who study the conditions for international cooperation) to direct their attention more toward international law. Beyond this cooperation strategy, strategic partnerships between international lawyers and social scientists might obviate some of the need to produce international law expertise within extant graduate programs. Despite some problems, such strategic partnerships also bring comparative advantages, including base knowledge and methodological sophistication.

\section{The Problem of Focus (and Its Corollaries)}

It may seem tautological to say that few political science studies of international law exist because few scholars ask questions about international law as a primary focus. Behind this explanation is the fact that most studies are not centrally concerned with international law as a dependent variable. Very few studies ask questions about how international law is formed or how it evolves. With some exceptions (e.g., women's studies), fields of study or research milieus develop and/or are defined by reference to the dependent variable.

Unfortunately, international law usually arises only when scholars are concerned with some other matter, such as cooperation in trade, state decisions to use military force, and the like. That is, international law is considered as a possible independent variable affecting international behavior. Too often, international law is not suitable as an independent variable. International law traditionally has evolved slowly and thereby often varies little over time; classic social science methodology depends on variations in the independent variable to account for variations in the dependent variable. For example, how does one explain national decisions to engage in trade dumping at a given time when treaty provisions against such practices have been in place for years?

A related problem is separating the impact of international law from that of self-interest (the heart of rational choice approaches). There is a tendency to attribute actions to utilitarian motivations rather than legal ones, even when they both predict the same behavior. Exacerbating this problem is that because international law is primarily consensual, it is likely there will be strong convergence between utility-seeking and law-abiding behavior. The attempt to separate these is often futile (a similar problem, although not insoluble, exists for international norms as well), and most scholars opt to focus on self-interest as the default option. Accordingly, in the final wash, international legal considerations rarely survive as purported influences on international behavior.

Scholars must focus on international law issues as the phenomena to be explained. There are many broad questions: When do international treaties form around a given issue? To what extent do states comply with international law? (Such a question clearly moves international legal compliance from a predictor to an outcome variable.) These questions might be studied profitably across a variety of issue areas to build knowledge and promote generalizations. Further- 
more, such inquiries do not start from theoretical scratch, as they can be informed by the plethora of works on regimes and international norms (for example), which ask related questions or postulate similar processes for international cooperative behavior.

\section{The Problem of Data}

Ideally, theoretical concerns drive data collection, and most major data sets in political science are developed in this causal sequence. Nevertheless, as a practical matter, data availability often conditions the kinds of questions asked and the methods employed in political science; the hegemonic impact of the National Election Study data on the field of American politics is only one, but nevertheless a prime example. Of course, not all international relations research is data based-far from it. Yet the lack of data on international law and related concerns inhibits research related to that subject matter. It is especially limiting when one wishes to ask questions with law as the dependent variable and go beyond small $\mathrm{N}$ case studies.

The lack of international law data partly stems from the sources of the phenomena. Until the last twenty to forty years, much international law derived from custom. As customary law was largely unwritten and often imprecise, it was difficult to discern exactly what it stated and which states specifically subscribed to it (although in theory it applied to all). Customary law formation is also a process, something that is difficult to translate into data, which tend to center on discrete actions at fixed points in time. Other sources of international law, such as general principles or jus cogens, are similarly difficult to translate into variable data.

The increasing trend toward codification of international law facilitates datagathering efforts in international law. Mere lists of treaties are not the equivalent of data per se, but they do provide a potential starting point. The U.N. Treaty Series is a collection of all international agreements since 1946, including parties to the agreements, classified by topic area. ${ }^{6}$ Such a list might be converted to data that assist answering questions about networks of interdependence in given issue areas, similarity of preferences or alignments across states, or the likelihood of agreements between hostile states.

Although the study of international law would benefit from more and varied data collections, two major impediments stand in the way. First, among those most conversant in international legal study, few are oriented toward the behavioral or social scientific approach or have the data-generation or analytical skills to put together such data sets. Second, data construction presents a collective goods problem in that the payoffs are longer term and disproportionately low (relative to the investment) for those who put such data sets together. Further-

${ }^{6}$ See www.un.org/Depts/Treaty. 
more, many social science funding agencies have increasingly looked askance at providing support for large data-collection projects, even when the products might be widely used.

\section{Conclusion}

Creating a new research milieu within international relations, or more broadly within political science, is not an easy task. There is a tension between creating an autonomous identity that offers innovative and interesting questions about some phenomena and not severing ties with the rest of the discipline. Severing ties presents a special risk (we see elements of this in certain constructivist or feminist studies of international relations) that international law will not be informed by broader international relations theory nor contribute itself to theory development. Properly addressing the three problems highlighted above should lead to the appropriate balance. Nevertheless, the interconnections among the three problems demand a simultaneous attack, but it seems sometimes that the solution of one is a prerequisite for the other two.

\section{International Law: Stepchild in Political Science Research? A Rejoinder to Paul Diehl}

\section{Beth A. Simmons}

Paul Diehl has put on the table several important issues for those scholars who are interested in the role of international law in international relations. He has correctly identified one of the primary reasons why there is so little study of the role of law in our subdiscipline of political science: the theoretical primacy of realism, which has made such inquiries seem at best quaint and at worst dangerous and misleading diversions along the road to understanding war and peace.

Although there are important barriers to fruitfully integrating international law into the study of international relations, some of the problems listed by Diehl are not serious barriers and present promising opportunities for scholars who are interested in the role of law in international relations. For example, the "warm bodies problem" is not a serious barrier to systematic research. Critical mass is smaller than one might think and getting smaller all the time with the use of the Internet.

It is not at all obvious to me that we need large numbers for this field to take off in productive ways. Several other specialties within IR also had small numbers just a few years ago, and highly productive work has characterized these specialties nonetheless. Consider, for example, international monetary relations. This was a field that seemingly required much technical training in an area populated with scholars who sometimes displayed obvious disdain for 
political scientists, especially economists. Yet the compelling nature of the substantive problems alone has drawn political scientists to acquire the necessary expertise.

It seems to me that the barriers are even lower for the acquisition of whatever legal expertise is necessary to research international law. How much "expertise" is really necessary, anyway? It also seems to me that political scientists need to know enough law to be able to understand how much it creates incentives or disincentives for particular kinds of political action and policy choice. It is not necessary to become a specialist to be able to read, absorb, and competently grasp the subject matter for this purpose. At the risk of giving offense, I submit that it is not that hard to comprehend enough law to be able to ask and even answer questions that are interesting for the study of international relations.

Additionally, I do not think that political scientists can or should come to the study of law through legal specialization. Most of us will study law only because it affects in important ways something we really care about-how wars are fought, how trade is conducted, and whether human rights are respected. This substantive focus is not "unfortunate." It is healthy because it provides a concrete motive for learning about law. In my view, it is a good thing for political scientists to come to the law, to quote Diehl, "only when scholars are concerned with some other matter, such as cooperation in trade, state decisions to use military force, and the like." After all, if we come to the law as specialists or study law for its own sake, our lectures and our research will begin to sound like the recitations of legal doctrine that nearly killed this subfield of IR two decades ago.

Is it a problem that many scholars have developed a teaching expertise in international law but not a research one? My experience is that students today do not let you easily accept this dichotomy. When teaching international law to undergraduates, at Duke and at Berkeley, I had to deal with the skepticism that any of this "mattered" to the conduct of foreign policy or important international outcomes that we might care about. The students simply would not let me lecture without pressing me in some way on this point. I had to think about it, and the more I did, the more I realized I did not know. But the more I tried seriously to provide them answers, the more I ended up doing nascent research. So I do not think this strict dichotomy can last long in all cases. Students are skeptics; they no longer allow teachers simply to recite legal doctrine-not while NATO is dropping bombs without Security Council approval, as in Kosovo in 1999.

Finally, to the extent that the warm bodies are relatively few, this provides an opportunity to do cutting-edge research. There are advantages to being in a small pool. The fact that there are relatively few people working on explaining the creation and evolution of international law and its effects on state behavior raises the payoffs to those who are willing to labor in this field. If you were the 
editor of a major journal, which would you rather publish, the 197th article on democratic peace or a careful examination of the extent of law compliance among sovereign states?

In sum, the question is not whether we can acquire the necessary expertise. We need not be specialists; sufficient expertise is pretty easy to acquire, and there is a growing legal community with whom we can form strategic alliances. The question also is not whether we can increase our ranks. This is an epiphenomenon of the inherently compelling nature of the problems we are tackling. The real question is: Can we profitably study international law as political scientists? Here we face serious challenges.

For one thing, international law can best be thought of as an endogenous yet consequential variable, that both needs to be explained and has an influence on outcomes we care about. After all, governments spend time, energy, and political resources negotiating agreements because they expect them to have some kind of impact on outcomes. We need theories and evidence that take this endogeneity into account.

Second, we should be willing to theorize about international law as interest driven. Diehl points out that there is a tendency to attribute actions to utilitarian rather than legal motivations, even when both predict the same behavior. This is as it should be. Interests are the default explanation in political science, and justifiably so. In most cases, there is no point in trying to deny that interests are the primary drivers of state behavior in IR. The challenge is to design research that is able to address the question as to whether legal considerations have any independent impact on states' decisions.

Conceptually, this should not be difficult to imagine: governments voluntarily accept obligations that they find inconvenient to keep later. This happens all the time, so there should be plenty of opportunity-despite the endogeneity problem-to distinguish interest-driven behavior from behavior that flows from a legal commitment. The key is to choose carefully cases in which short-term interests might predict $\mathrm{x}$ but legal commitments predict $\mathrm{y}$. Political scientists control for things all the time; in principle, it should be no more difficult to do so in the case of short-term interests versus longer-term legal considerations, as long as we have political theories about what constitutes a short-term interest.

The job is not complete if we simply design controlled research that demonstrates a correlation between legal requirements and state action. It is also necessary to clarify the mechanism by which we expect international law to influence state behavior or policy choice. The theoretical frontier is to determine why the law matters to behavior, if indeed it does. The explanation cannot be devoid of an "interest" explanation. The most convincing explanations will be those that give a good reason to believe that the existence of legal institutions changes the interests governments have in particular kinds of behavior. We need to think of what mechanisms could be at play in changing the context 
of choice: do legal commitments change expectations about behavior such that violating obligations increases costs? What kinds of costs are involved: domestic political punishment, market punishment, or punishment from other states or international institutions? Under what conditions can we expect these various mechanisms to come into play?

In conclusion, I submit that the most difficult issues are conceptual and methodological, not data and numbers of researchers. The world is getting more rule-intensive-more "legalized." This is an empirical reality that is difficult to ignore. The increasing number of transnational actors causes it, coupled with an accelerating interdependence and globalization that makes more rules imperative for greater political cooperation and proliferating economic intercourse.

Once we have framed the questions in interesting and researchable waysand in ways that will at least speak to the concerns of critics who see nothing but short-term interests in every governmental policy choice - the warm bodies will eventually come. I predict that with the number of energetic graduate and even undergraduate students who are interested in these questions, the appropriate data will not be far behind.

\section{Working With Political Scientists: A LAWYER'S EXPERIENCE}

\section{DORINDA G. DALlMEYer}

Since 1991, I have served as a participant, lecturer, and twice the coorganizer of a summer workshop on international organization, which was sponsored jointly by the American Society of International Law (ASIL) and the Academic Council on the United Nations System (ACUNS). This two-week workshop is designed to bring together promising young scholars, with newly minted Ph.D.s in international relations, who are researching areas in international law. The hope is that in this intensive workshop experience, participants will be stimulated to begin interdisciplinary cooperative research, or failing that, at least gain an appreciation of the terms and approaches of the counterpart field.

I would like to make several points in light of my experience during the past eight years and from these varying perspectives. Generally, it has been difficult to achieve numerical parity between representatives of international law and international relations in selecting the two dozen participants for the summer workshop. Each year there are far more students, both from the United States and abroad, completing dissertations in international relations than pursuing international law specialties. It is partly due to the greater demand for persons to teach multitudes of students in political science, as opposed to the relatively 
limited number of students in law school. It is also partly due to the difference in credentials expected of law faculty versus political science faculty.

The Ph.D. degree is an absolute minimum for political science faculty; the holder of the equivalent S.J.D. is a rare bird. An unscientific survey of the Directory of Law Teachers, published by the Association of American Law Schools, reveals that most of the professors teaching international law-many of the younger and most innovative writers in the area-do not hold a degree beyond the J.D., completed after three years of study following the undergraduate B.S. or B.A. degree. Compounding this difference is the fact that accreditation standards effectively prevent law schools from offering a J.D. in international law. Occasionally, we find a certificate program or more commonly an area specialization, but that is about all; it is in keeping with the domestic focus on law that has typified law school pedagogy, at least until recently.

The result is a person interested in international law, perhaps marginalized as far as the perceived centrality of the enterprise in relation to the overall focus of the law school, and a person ensconced in a "professional" school as well. Although it would be unfair to characterize a law school education as simply the production of competent technicians, the approach is grounded in diagnosis and prescription. In most instances, jurisprudence and theory is not a central theme. If jurisprudence is taught at all, for better or worse, it is taught in a seminar setting, ensuring that only a self-selected few will grapple with themes of realism, etc., which are standard fare for students in international relations.

Mixing international relations graduates with international law graduates can produce unexpected results. The general impression is that law students behave like tiger sharks, but I have seen them rendered speechless by Ph.D. candidates from the field of international relations. Remarks such as "Well, I've listened to your presentation, and I still don't know what your dependent variable is" can lead to slack-jawed perplexity among the lawyers in the crowd. Various schools of thought drilled into the international relations students through preparation for a seemingly endless stream of qualifying examinations and tossed off liberally as shorthand in conversation leave the lawyers gasping. More than once there has been a note of condescension, such as, "You don't even have a theory. Why, you're just describing things." My impression also is that international law is often viewed by those outside the field as a quaint enterprise of the striped-pants set, almost an immutable creature preserved in amber, and a diversion from the real story of policy choice.

Yet to the international law scholar in the postwar era, there has been an explosion of subject matter on international law in its broadest sense, including international institutions and regimes. There also has been a more conscious effort by legal scholars to directly address methods by which they conduct research in international law. This movement is most admirably on view in the 
April 1999 issue of the American Journal of International Law, in which twelve prominent legal scholars contributed to a symposium on method in international law. It included international relations as one of the methodsalthough as interpreted by lawyers.

Understandably, the organizers of the symposium could not discuss all methods of approaching international law, but instead concentrated on seven: positivism, policy-oriented jurisprudence, international legal process, critical legal studies, feminist jurisprudence, law and economics, and a purposefully interdisciplinary approach combining international law and international relations. Although by necessity the organizers asked the contributors to focus on one distinct topic rather than the gamut of applications, the resulting case studies produced valuable insights on how methods differ in their approach and efficacy. As a result, we now can point to this comparative work to indicate the multitude of methods available for analysis not only by international law scholars, but also by international relations specialists.

In much interdisciplinary work, it is difficult to create a jargon-free zone unless it is pursued consciously from the start. An example of this problem is the different meanings the two groups attribute to the word "norm." One tactic is to start with an examination of papers that presents comparative research strategies and encourages questions about terminology. For some groups in the workshop experience, the differences between the disciplinary approaches have been major problems; other groups have cleared the hurdle quickly and were astonished to think it had been such a stumbling block for others.

As with any enterprise, a long-term research relationship needs to be established. The intensive, sometimes "boot camp" atmosphere of the workshops can lead to rapid development of informal working groups who share common subject matter interests-e.g., environmental regimes, postconflict peace building. Several self-selected research groups that formed around common core interests during the workshop have succeeded in getting financial support from foundations to continue their collaboration.

A recent development for international law scholars, which also should make international law research more appealing to political scientists, is the rapid increase in the availability of international documents online. In the past five years, we have benefited from a revolution in timely access to documentation that formerly took months and sometimes years to appear.

Collaboration is a delicate relationship, regardless of the subject matter area and the ease of access to information. Cross-disciplinary collaboration continues to be rare. Yet it offers the opportunity for each party to return to international law or international relations and apply the insights learned from the disciplinary detour. I believe we are seeing the greatest impact among the participants in the ASIL/ACUNS workshops in more reflective analysis within the subject matter of international law. 


\section{Doing Collaborative Research on International Legal Topics: An Autobiographical Account}

\section{HAROLD K. JACOBSON}

This is an account of my complicated relationship with international law. I beg the readers' indulgence for my reminiscences in the hope that they encompass a story of broader import. The story is one of rejection, abandonment, rediscovery, and efforts to achieve rapprochement. Given international law's role as a parent of modern international relations studies, the account bears an undeniable relationship to family life cycles.

\section{Rejecting International Law}

I entered the graduate program in international relations at Yale University in September 1950 and left as a freshly minted Ph.D. in June 1955. After two years at the University of Houston, I joined the University of Michigan Department of Political Science in September 1957 and have remained a member of the Michigan faculty since.

The 1950s and early 1960s were heady days for those studying international relations through the lens of political science. Many of us, like many who came before and after us, were deeply committed to our studies being relevant to achieving peace, prosperity, and human dignity. Having absorbed both E. H. Carr's The Twenty Years' Crisis and Hans Morgenthau's Politics among Nations, we knew we had to be realistic. ${ }^{7}$ At Yale and Michigan and many other places, we were also deeply committed to developing science. Quincy Wright's A Study of War provided a template for amassing data and systematically deriving generalizations and testing theories. ${ }^{8}$ We were convinced that we could be relevant, realistic, and rigorous.

These were the early days of the behavioral revolution. We saw ourselves as budding scientists. Following the ways of natural science, we would adhere to the tenets of logical positivism. There was much emphasis in our graduate training and early self-learning on gaining insights from the behavioral sciences, especially psychology, sociology, and anthropology. We were taught that our goal should be to search for generalizations about behavior in international

${ }^{7}$ Edward Hallett Carr, The Twenty Years' Crisis, 1919-1939: An Introduction to the Study of International Relations (London: Macmillan, 1949); Hans J. Morgenthau, Politics among Nations: The Struggle for Power and Peace (New York: Alfred A. Knopf, 1949).

${ }^{8}$ Quincy Wright, A Study of War (Chicago: University of Chicago Press, 1942). 
relations. We thought that we could discover laws that governed international behavior. Although our positivist proclivities prohibited us from proclaiming it, we hoped that the generalizations would form the basis for prescriptions.

Political scientists attempting to develop generalizations about political behavior tended to deemphasize institutions, and international law did not figure prominently in our search for generalizations about international behavior. Although Carr's The Twenty Years' Crisis had a sophisticated treatment of international law, the section concluded by rejecting law and judicial settlement as a prescription for world order. ${ }^{9}$ Carr argued that law reflected the interests of the powerful. Because of the way it was formed, it could not easily adjust existing rights. He counseled extricating "ourselves from the blind alley of arbitration and judicial procedure." ${ }^{10}$ Morgenthau also discussed international law in detail, but he, too, rejected law as a formula for world order. ${ }^{11}$ For Morgenthau, the decentralized character of law, the way it was formed, adjudicated, and enforced, rendered it inadequate to deal with the essential issues of war and peace.

Percy Corbett taught a course in international law at Yale. Accepting Carr's and Morgenthau's arguments, I did not take it. Given my adherence to Carr's and Morgenthau's perspective, military strategy by Bernard Brodie seemed more relevant. Harold Lasswell taught in the Yale Law School, and I read his books. They seemed like political science.

My dissertation stressed Soviet behavior in the United Nations and the clash between the USSR and the West. There was little law in it. When I came to Michigan, I proposed dropping law from the title of graduate and undergraduate courses on international law and organization.

\section{Rediscovering International Law}

Even in the 1950s, I could not escape a nagging sense that to ignore international law was to ignore an important part of international relations. Arnold Wolfers lectured and wrote about states' pursuit of milieu goals, which pertained not to national possessions but "to the shape of the environment in which the nation operates." 12 He pointed out that if it were not for such goals "peace could never become an object of national policy." ${ }^{13}$ He listed efforts to promote international law and establish international organizations as prominent

${ }^{9}$ Carr, Twenty Years' Crisis, pp. 170-223.

${ }^{10}$ Ibid., p. 207.

${ }^{11}$ Morgenthau, Politics among Nations, pp. 209-242.

${ }^{12}$ Arnold Wolfers, Discord and Collaboration: Essays on International Politics (Baltimore, Md.: Johns Hopkins Press, 1962), p. 73.

${ }^{13}$ Ibid., p. 74. 
examples of milieu goals. In a guest lecture before Yale graduate students in international relations, Philip C. Jessup gave a version of his ideas about transnational law. His approach was novel and stimulating.

This nagging sense grew as the second half of the twentieth century developed. Although Carr's and Morgenthau's positions may have been appropriate for analyzing the interwar period, the post-World War II period differed considerably from the period on which they based their conclusions. International relations came to encompass much more than arguments about the control of territory and issues of war and peace. Even traditional security and military issues were redefined as the world contemplated the horrendous potential of weapons of mass destruction. Economic issues became more prominent, as did concerns with human rights. Then environmental issues were put on the international agenda.

Moreover, the project to discover universal laws governing behavior fell short of our aspirations. We found that we could not understand and explain behavior without including history and institutions in our analyses. When confronted with similar stimuli similarly placed and endowed, actors responded differently. We had to rediscover institutions to account for the differences, and in the process, some of us at least rediscovered international law.

Along this route, I became engaged in four projects that involved working collaboratively with international legal scholars. The first was a study of the negotiations for the limited ban on testing nuclear weapons. Even if, as Carr and Morgenthau argued, international law could not be used to solve deep political conflicts, it could play a role in limiting the means used to pursue those conflicts. The second was a study of the functioning of environmental institutions in the decade after the Stockholm conference. The third was a study of the extent of compliance with international environmental regulations. Both projects were based on the sense that international regulation would be required to ameliorate environmental problems that transcended state borders. The fourth project is an ongoing study of the uses of military forces under the auspices of international institutions and democratic accountability. Despite Morgenthau's skepticism, military forces have been deployed under the auspices of international institutions almost sixty times since the end of World War II. Collective security works to a limited extent.

Can democratic accountability be assured and maintained when military forces are deployed under the auspices of international institutions? The second and fourth projects were conducted under the auspices of ASIL. The first project was a two-person collaboration between a political scientist and an international legal scholar. The three other projects each involved a large number of participants, several of whom were international legal scholars. These four experiences provided stimulating challenges and rich and rewarding opportunities. Membership on the Board of Editors of the American Journal of International Law has helped me put these experiences in a broader perspective. 


\section{Seeking a Rapprochement: Challenges in Exploring International Law}

Since I was not trained in international law, I have felt that I could work only on issues that involved international law as a central component in collaboration with someone trained in international law. Finding a collaborator is difficult. International law and the study of international relations within political science have become separate disciplines. Each has its own jargon, epistemology, and methods. Both international lawyers and political scientists have their own career incentives. To collaborate risks moving one or the other side out of the framework that will provide career rewards.

I have been very fortunate. Eric Stein and I studied the limited test ban negotiations together. ${ }^{14} \mathrm{He}$ was initially trained at Charles University and then at the University of Michigan. He served in the Department of State and represented the United States in the United Nations before he returned to the faculty of the University of Michigan Law School. His early training at Charles and his experience in the Department of State made him receptive to collaboration with nonlawyers. Edith Brown Weiss and I were codirectors of the project on national compliance with international environmental accords. ${ }^{15}$ She earned both a J.D. from Harvard and a Ph.D. in political science from the University of California at Berkeley. David Kay, with whom I codirected the project on environmental protection, was a political scientist, but he was also director of studies at ASIL. ${ }^{16}$ Charlotte Ku, with whom I codirect the project on using military forces under the auspices of international institutions, received her Ph.D. from the Fletcher School of Law and Diplomacy. She studied both international relations and international law, the latter under the guidance of Leo Gross, a prominent international legal scholar. My collaborators have all been intellectually open to collaboration, well prepared to engage in collaboration, and for one reason or another not susceptible to the career risks that such collaboration might involve.

Once appropriate collaborators are found, new challenges arise. Communicating is a major challenge. International legal scholars and political scientists who study international relations use the same words, but the meanings are frequently different, although they may be related. For political scientists, "pos-

${ }^{14}$ Harold K. Jacobson and Eric Stein, Diplomats, Scientists, and Politicians: The United States and the Nuclear Test Ban Negotiations (Ann Arbor: University of Michigan Press, 1966).

${ }^{15}$ Edith Brown Weiss and Harold K. Jacobson, Engaging Countries: Strengthening Compliance with International Environmental Accords (Cambridge, Mass.: MIT Press, 1998).

${ }^{16}$ David A. Kay and Harold K. Jacobson, Environmental Protection: The International Dimension (Totawa, N.J.: Allenheld Osmun, 1983). 
itivism" means an epistemology based on the fact-value distinction. For the international legal scholars, "positivism" is a school of thought. Bruno Simma and Andreas L. Paulus summarized the classic positivist perspective as follows: "Law is regarded as a unified system of rules that, according to most variants, emanate from state will. This system of rules is an 'objective' reality and needs to be distinguished from law 'as it should be." "17 The quotation shows the similarities and differences between the two disciplines' use of the term positivist.

International legal scholars and political scientists who study international relations frequently have different goals. We are all reformers, but lawyers are unabashedly so. Legal scholarship, even that of positivists, often involves advocacy. Political science scholarship seldom does, at least explicitly.

International legal scholars and political scientists think differently. Because we are trained to seek generalizations, political scientists try to create models and think in terms of establishing causal relationships through statistical analyses. Lawyers are frequently skeptical of political science techniques. Because law seeks to treat similar cases similarly, lawyers seek general solutions. Political scientists sometimes are more inclined to seek differentiated solutions. International legal scholars sometimes tend to think in terms of categories rather than continua, a favorite tool for political scientists to employ in arranging data.

Finally, there is a difference that may seem trivial but it is not. International legal scholars and political scientists differ on the desirable length of their products. International legal scholars have a much greater tolerance for long books.

\section{Seeking a Rapprochement: Opportunities Opened by Exploring International Law}

Many interesting opportunities arise in researching international law with international lawyers. International legal scholars take seriously the importance of institutions, defined broadly as Douglass North defines them: "Institutions are the rules of the game in society, or more formally, are the humanely devised constraints that shape human interactions." 18 They are professionally predisposed to believe that law affects behavior. They base their careers on the assumption that North and others are right.

International legal scholars think a lot about how institutions affect behavior, and their scholarship provides a rich source of hypotheses. Suggestive examples from common wisdom found in international legal scholarship include the

${ }^{17}$ Bruno Simma and Andreas L. Paulus, "The Responsibility of Individuals for Human Rights Abuses in Internal Conflicts: A Positivist View," American Journal of International Law 93, No. 2 (1999), pp. 302-316.

${ }^{18}$ Douglass C. North, Institutions, Institutional Change and Economic Performance (Cambridge, U.K.: Cambridge University Press, 1990), p. 3. 
following: the more precise a treaty commitment, the more likely that there will be compliance with the commitment; hard law is better than soft law; the more a country is involved in negotiating a treaty, the more likely it will be to comply with the obligations set forth in the treaty; the greater the independence of the secretariat of an international governmental organization (IGO), the stronger the IGO will be; a single-headed secretariat will result in a stronger IGO than a multiple-headed one; and the greater the financial autonomy of an IGO, the stronger the IGO will be. Such hypotheses beg empirical testing, and work has begun to test them.

There can be important synergies between international law and international relations scholarship, synergies that yield benefits for both scholarship and policy. The negotiations that resulted in the treaty banning nuclear weapons tests in the atmosphere, outer space, and under water and subsequent developments, with respect to compliance, provide an example. I learned about these things from my study of the partial test ban negotiations and then later participated in some of the developments with respect to compliance.

During the initial phase, the test ban negotiations were driven by the traditional concept of international law and organization that there would have to be an elaborate international organization to monitor nuclear testing and impose sanctions if the ban on testing were violated. In January 1961, after the negotiations had been in progress for several years and were stalemated, Fred Charles Iklé, a political scientist working for the Rand Corporation, published an article that challenged such thinking. Iklé suggested that instead of relying on a complicated process of adversarial monitoring by international organizations, using national detection systems and simply discontinuing the treaty if one side felt that the other had violated its obligations would be sufficient. This article and the Rand research on which it was based led to an important breakthrough in the negotiations and paved the way to the series of arms control agreements that were negotiated subsequently. ${ }^{19}$

The experience with these arms control agreements and other international accords, which were negotiated to deal with environmental and other administrative issues, led to new thinking by international legal scholars about compliance with international agreements. Abram and Antonia Chayes's article, "On Compliance," and book, The New Sovereignty, are important examples of this new thinking. ${ }^{20}$ The Chayes argued that while sanctions played a relatively

${ }^{19}$ Fred Charles Iklé, “After Detection—What?” Foreign Affairs 39, No. 2 (1961), pp. 208-220.

${ }^{20}$ Abram Chayes and Antonia Handler Chayes, "On Compliance," International Organization 47 (1993), pp. 175-206; Abram Chayes and Antonia Chayes, The New Sovereignty: Compliance with International Regulatory Agreements (Cambridge, Mass.: Harvard University Press, 1995). 
minor role in inducing compliance with international accords, management techniques were more frequently the determinant. This argument provoked a counterargument by political scientist George Downs and his colleagues, who argued that the more important the agreement, the more important were sanctions. ${ }^{21}$ This exchange provoked an important debate on the role of sanctions in promoting compliance with international accords. The project that I directed with Edith Brown Weiss fits in this debate.

\section{The Promise of Rapprochement}

Anne-Marie Slaughter and others have argued that international relations scholars and international legal scholars should embark on collaborative research programs. ${ }^{22}$ They argue that there are topics that can profit from collaboration and that the time is ripe for collaboration. I strongly support their plea. I personally have learned much from my work with international legal scholars.

This is not what I expected when I left Yale in 1955 and came to Michigan in 1957. Were Carr and Morgenthau wrong? Was the behavioral revolution misdirected? I think that the answer to both questions is no. Carr and Morgenthau were right in that international law could not have resolved the international conflicts of the interwar period. They did not fully anticipate how international relations would develop after World War II. International law will be enormously relevant to the broad agenda of international relations in the twenty-first century.

We should not forget Carr's and Morgenthau's warnings. International law continues to be made by the powerful, and the mechanisms for accomplishing peaceful change internationally still fall far short of what can be done domestically. As Morgenthau stressed, the enforcement process internationally continues to be decentralized, which is at the root in some respects of the ChayesDowns debate. We were right to try to be scientific, but our units of analysis are not individuals but individuals organized in collectivities. We cannot ignore institutions as North has defined them, and institutions include most importantly international law.

International relations scholars are ready to heed the call of Slaughter and her colleagues. I hope that the journey we have traveled in the past decade has helped to prepare us. As Slaughter and her colleagues argue, and my experience convinces me, the benefits of collaboration will be rich.

${ }^{21}$ George W. Downs, David M. Rocke, and Peter N. Barsoom, "Is the Good News about Compliance Good News about Cooperation?" International Organization 50, No. 3 (1996), pp. 379-406.

${ }^{22}$ Slaughter, Tulumello and Wood, "International Law and International Relations Theory." 


\section{CONCLUDING IMPRESSIONS}

\section{Charlotte Ku}

All four essays acknowledge that opportunities for political science research in international law exist, but that the challenges of effectively pursuing such work need to be recognized. The writers recognize the differences between the two fields but conclude that both political scientists and lawyers can benefit from greater familiarity with the work of the other.

It is important that lawyers and social scientists recognize that their goals influence their methods and that their goals differ. A lawyer is generally more prescriptive than a social scientist and is interested in changing behavior. A social scientist eschews prescription and seeks to understand behavior but not to change it. A lawyer wants to understand enough about behavior to achieve certain goals. A social scientist wants to understand behavior, whether or not the study produces any immediate policy or practical effects.

This contrast sets up a basic incompatibility. The lawyer wants to know how something can be achieved. The social scientist wants to understand some element of behavior. The lawyer looks at individual instances and collects "evidence," often through descriptions of behavior or anecdotes. The social scientist will look for research questions where there are sufficient data to analyze. Whether a question can be researched or not is basic to a social scientist. Lawyers are problem solvers who identify issues and find valid purpose in addressing those issues, no matter how much information is available. Dorinda Dallmeyer's and Harold Jacobson's personal experiences illustrate the basic intellectual differences that exist between law and social science.

But there are changes that signal opportunities for working more closely together. International law is moving away from a states-only system toward one that includes a variety of actors and a continuum of law, ranging from treaties to informal agreements. ${ }^{23}$ Neither all actors nor all legal instruments carry the same weight, but evidence is mounting that there is an ongoing interplay of modalities that influence international relations. These modalities include those that we have traditionally studied as individual rather than related units, such as international politics, institutions, and instruments, together with domestic politics, institutions, and laws. This recognition is leading to such collaborative undertakings as a project led by former American Political Science Association president Robert Keohane "to examine the boundary between pol-

${ }^{23}$ Rosalyn Higgins, Problems and Process: International Law and How We Use It (Oxford, U.K.: Clarendon Press, 1994); Christine Chinkin, "The Challenge of Soft Law: Development and Change in International Law," International and Comparative Law Quarterly 38 (1989), pp. 850-866. 
itics and law to understand what processes lead to the legalization of disputes management and what processes push toward political mechanisms." 24

International law may be information rich, but it may not appear to be data rich to a social scientist. Beth Simmons provides general guidance on how to take the information provided by international law and generate analyzable data. Work such as hers, if made accessible to international lawyers, can enhance the debate over whether international law is observed most of the time, as Louis Henkin asserts, ${ }^{25}$ and provide a much richer pool of evidence from which to assess effectiveness of an international law or rule. While we are increasingly struck by the inadequacies of the traditional elements of law and power to understand the phenomena we witness in newspaper headlines, our disciplinary and intellectual boundaries seem harder to overcome. As these essays suggest, the differences are valuable and important to maintain. Nevertheless, new problems might benefit from new tools-tools that might be forged from collaboration between lawyers and social scientists for better understanding of the many perspectives of conflict and cooperation in the world today. The authors in this roundtable have given the benefit of their experience and insight. They acknowledge difficulty and difference but urge continuation of the effort. Collectively, we hope readers of these essays will agree and answer our call.

${ }^{24}$ Peter A. Gourevitch, "Robert O. Keohane: The Study of International Relations," PS: Political Science and Politics 32, No. 4 (1999), p. 626.

${ }^{25}$ Louis Henkin, How Nations Behave (New York: Columbia University Press, 1979). 